\title{
KAROL STEFAŃCZYK
}

Uniwersytet Warszawski

stefanczyk.karol@gmail.com

\section{TELESKOPICZNE OKO. 0 AMERYKAŃSKIM POWOJNIU CZEStAWA MILOSZA EWY KOŁODZIEJCZYK}

\section{Abstract}

The Telescopic Eye. Ewa Kołodziejczyk's Amerykańskie powojnie Czesława Miłosza Amerykańskie powojnie Czesława Miłosza [Czesław Miłosz's American postwar period] is a book based on Ewa Kołodziejczyk's research in the Yale University library, where she found some texts written by Miłosz during his first stay in the US as a representative of the Polish communist government. Kołodziejczyk splits Miłosz's activites into diplomatic, popularizing, and literary ones. Her main concept is "the telescopic eye". It lets her tie all Miłosz's interests during his stay in the US. Also, such concept emphasizes Miłosz's rapacious attitude towards the world as a whole. Thanks to that, Kołodziejczyk is able to create a coherent, convincing narration of Miłosz's short, but crucial episode in the late 40s.

Key words: modernism, American poetry, postwar period, communism, history of ideas.

Słowa klucze: modernizm, amerykańska poezja, powojnie, komunizm, historia idei.

Tytuł książki Ewy Kołodziejczyk może być mylący. We współczesnej polszczyźnie wyraz „powojnie” odnosi się do wydarzeń, które miały miejsce nawet wiele dekad po zakończeniu II wojny światowej i wiążą się z tzw. ładem pojałtańskim ${ }^{1}$. Tymczasem Kołodziejczyk postępuje zgodnie z pod-

1 Wynika to być może z wpływów angielszczyzny, o czym przekonuje choćby tytuł książki historyka Tony'ego Judta Powojnie (ang. Postwar), na którą Kołodziejczyk nota bene wielokrotnie się powołuje. 
stawowym znaczeniem, definiując to pojęcie bardzo wąsko - jako okres bezpośrednio po wojnie. W przypadku biografii Czesława Miłosza wyznaczyć te ramy czasowe było jej jeszcze łatwiej. Obejmują one pięciolecie 1945-1950, gdy poeta przebywał w Stanach Zjednoczonych, pełniąc funkcję attaché kulturalnego na usługach krajowych władz komunistycznych.

Niewykluczone jednak, że książka wprawi w zdziwienie czytelnika przyzwyczajonego do szerokiego rozumienia powojnia, szczególnie że jak wiadomo - Miłosz powrócił na amerykański kontynent w latach 60., otrzymawszy posadę profesora na Uniwersytecie w Berkeley. Początkowe zaskoczenie powinno jednak z czasem ustąpić miejsca zrozumieniu, a następnie-podziwowi. Trwający przynajmniej dwie dekady okres kalifornijski jest bowiem zbyt obszerny, by włączyć go do narracji Kołodziejczyk. Autorka i tak wykonała imponującą pracę, opisując swoje badania na prawie 600 stronach. Nie możemy mieć do niej pretensji, że ograniczyła się tylko do pięciu lat z życia Miłosza. Przeciwnie, rozmach Amerykańskiego powojnia dowodzi, że przed badaczami noblisty wciąż stoi sporo wyzwań, a głośna biografia pióra Andrzeja Franaszka (Miłosz. Biografia, Kraków 2011) wcale nie wyczerpuje tematu.

Jak decydująca była druga połowa lat 40. dla samorozwoju Miłosza, o tym Kołodziejczyk stara się przekonać czytelnika od pierwszych stron swojej rozprawy. By uporządkować zgromadzony materiał - zarówno ten dostępny od lat w drukach prasowych i książkowych, jak i ten przechowywany dotychczas w amerykańskich archiwach (głównie Biblioteki Uniwersytetu Yale, gdzie Kołodziejczyk przebywała na stypendium) - autorka wydzieliła następujące aktywności poety: dyplomatyczną, popularyzatorską, publicystyczno-eseistyczną, tłumaczeniową oraz poetycką. Kolejność aktywności odpowiada spisowi treści Amerykańskiego powojnia, ale wyznacza też, być może nieświadomie, dwa bieguny zainteresowań Miłosza. Książka rozpoczyna się od omówienia działalności politycznej pisarza, a więc od analizy tych tekstów, które podyktowane były bieżącymi potrzebami dyplomatycznymi. Kończy się zaś interpretacją utworów poetyckich i eseistycznych, do których poeta przywiązywał największą wagę. Innymi słowy, Kołodziejczyk, choć nie sięga po narrację chronologiczną, uchwytuje na gruncie kompozycji rodzące się przekonanie Miłosza, że należy zerwać współpracę z rządem komunistycznym i wybrać niezależny los intelektualisty.

Mówiąc o autorze Ocalenia, korzystam z kategorii ,intelektualista” nieprzypadkowo. Wydaje się ona najbardziej pojemna, by objąć wszystkie wymienione wyżej aktywności Miłosza. Niewykluczone, że w oczach samego 
poety nie były one od siebie aż tak bardzo oddalone. Jak zwraca uwagę Kołodziejczyk, publicystyka lub odczyty były niejednokrotnie przestrzenią roboczą, miejscem, gdzie pisarz mógł wypróbować pewne koncepcje, skonfrontować je z reakcją publiczności lub ustawić własną dykcję wobec innych autorów (przykładem może być dyskusja wokół reportażu Johna Herseya Hiroshima; 327).

Wszechstronność lub, mówiąc metaforycznie, łakomstwo Miłosza miały jeszcze dwa inne źródła, oba są wyeksponowane w Amerykańskim powojniu. Pierwszym była tęsknota za dawnym wzorem intelektualnym, który pozwalał na pełniejszy ogląd rzeczywistości. Miłosz kreśli ten ideał w Rodzinnej Europie, której fragment Kołodziejczyk przytacza (197): „Reportażysta, socjolog i historyk mogli wtedy współżyć w jednym człowieku, zanim nie rozłączyli się z wzajemną dla siebie szkodą" (por. Miłosz 2001: 165). Drugim źródłem Miłoszowskiej ciekawości były okoliczności, za których sprawą poeta znalazł się w Stanach Zjednoczonych. Pisarz traktował pobyt w USA jako okazję do samokształcenia i osiągnięcia takiej „międzynarodowości umysłu" (48), która pozwoliłaby mu lepiej zrozumieć tragizm Europy.

Ambicje Miłosza, by możliwie sprawnie poruszać się po zawiłościach historii, ostatecznie kumulują się w metaforze „oka teleskopicznego” - metaforze, którą wylansował sam poeta, a którą Kołodziejczyk przejmuje i czyni lejtmotywem Amerykańskiego powojnia. Zasadniczą cechą Miłoszowskiego oka, kojarzonego gdzie indziej z „boskim” okiem (165) lub „wzrokiem absolutnym" (531), jest jego pojemność: zdolność do uchwycenia zdarzeń zmiennych w czasie i przestrzeni, zarówno ogólnych, jak i szczegółowych. Oko jest zatem metaforą, która pozwala wyjaśnić szeroki horyzont zainteresowań Miłosza oraz dialektyczne napięcie jego myśli, a jednocześnie pochodzi z prywatnego słownika poety. Decyzja Kołodziejczyk, by się tym obrazem posłużyć, jest więc w pełni uzasadniona. Oko pozostaje wprawdzie w pewnym napięciu z kompozycją książki - rozpisaną na szereg różnych aktywności Miłosza - ale jej nie unieważnia. Przeciwnie: Amerykańskie powojnie kończy się niejako apelem do czytelnika, zachętą do tego, by przebrnąwszy przez różne wcielenia poety, zdobył się na spojrzenie ogólne, relacyjne (531).

Oko, choć w książce Kołodziejczyk pełni funkcję głównej metafory, bywa uzupełniane innymi pojęciami. Próbując uchwycić istotę takich tekstów Miłosza jak cykl Życie w USA, autorka posługuje się wyrażeniem „warsztat sylwy” (187). W innym miejscu określa publicystykę pisarza mianem „literatury mediacji”, pożyczając to pojęcie od komparatysty 
Daniela-Henri Pageaux (273). Jeszcze gdzie indziej, opisując Notatnik nowojorski, stwierdza: „Narracyjnej alinearności notatnika towarzyszy dodatkowo - jak powiedziałby Krzysztof Zajas - cyrkulacja dyskursów, której celem jest osiągnięcie ideału heteroglosji” (292).

Powyższe pojęcia sygnalizują metodologię, która zdaje się najbliższa Kołodziejczyk. Sygnalizują jedynie, ponieważ autorka nigdzie jej wprost nie definiuje. Można więc podejrzewać, że Amerykańskie powojnie - pokłosie pracy o charakterze przede wszystkim archiwistycznym - inspirowane jest szeroko rozumianymi badaniami kulturowymi i porównawczymi. Takie zaplecze teoretyczne wydaje się oczywistym wyborem. Przedmiotem badań jest wszakże twórczość autora, który znalazłszy się w obcej, amerykańskiej kulturze, poznaje ją od środka, co rusz konfrontując swoje obserwacje z doświadczeniami europejskimi.

Trudno jednak nie odnieść wrażenia, że taka decyzja, choć najbardziej naturalna, jest zarazem najprostsza, a przynajmniej - najbezpieczniejsza. Te rozpoznania Kołodziejczyk, które dotyczą sylwicznego lub mediumicznego charakteru utworów Miłosza, są więc tyleż trafne, co niewiele wnoszące. Bywają oczywiście momenty, gdy komparatystyczne ujęcie okazuje się płodne. Przykładem niech będą uwagi o szkicu Massachusetts. Tam międzykulturowy dialog inscenizowany przez Miłosza toczy się w cieniu zbliżającej się Apokalipsy, która - powiada poeta odczytywany przez Kołodziejczyk - pochłonie także prowincjonalną, zaczarowaną Amerykę (283). Oto interkulturowość zyskuje kluczowy dla Miłosza, katastroficzny rys.

W większości przypadków interpretacjom Kołodziejczyk brakuje jednak głębi. Sprawiają wrażenie, jakby ślizgały się po powierzchni, jakby autorka jedynie z obowiązku sięgała po ,zewnętrzną” teorię. Cytowany wyżej fragment, w którym przywołany jest Krzysztof Zajas, obnaża kuriozalność niektórych wyborów Kołodziejczyk: wszak wątpliwe jest, czy uruchomienie pojęć dyskursywności lub heteroglosji wymaga przypisu do książki Nieobecna kultura. Przypadek Inflant Polskich. Zarzut ten możemy sformułować jeszcze inaczej, kładąc słabości na karb albo obranej metodologii - operującej niekiedy pojęciami tak ogólnymi, że wręcz pustymi semantycznie - albo olbrzymiego materiału badawczego, nad którym autorka musiała jakoś zapanować, określając podstawowe reguły.

Interpretacja zresztą nie wydaje się sednem tej książki. A przynajmniej nie interpretacja poszczególnych tekstów Miłosza. Kołodziejczyk, gdy przyznaje, że napisała Amerykańskie powojnie, ,chcąc być użyteczną” (21), wskazuje tym samym na inny cel swojej pracy. Jej rozprawa - poza tym, że 
przybliża czytelnikowi i omawia szereg tekstów dostępnych dotychczas jedynie w archiwach - wyznacza także ramy przyszłej dyskusji o roli powojnia w biografii Miłosza. To zasługa, której nie sposób przecenić. Kołodziejczyk formułuje te ramy na kilka sposobów.

Po pierwsze, wskazuje potencjalne tropy, za którymi w przyszłości mogliby podążyć badacze: zapytuje o rolę Herberta G. Wellsa w kształtowaniu się „refleksji postsekularnej” Miłosza (245), zwraca uwagę na brak muzyki jazzowej wśród zainteresowań poety (241), przypomina o niewydanej antologii poezji angielskiej (317).

Po drugie, mówi o Miłoszowskiej strategii zacierania śladów: krycia się ze swoją wiedzą oraz inspiracjami. Autor Trzech zim starannie rozdzielał przypisywane mu role. Do innych źródeł sięgał, pisząc sprawozdania dla rządu, a do innych, gdy realizował się w roli publicysty (184). Z tego powodu Kołodziejczyk wysuwa podejrzenie, że za tekstami poetyckimi stoi jeszcze inne zaplecze lekturowe. Układa więc listę autorów drukowanych w prasie czytanej przez Miłosza, autorów, do których jednak sam poeta (wtedy przynajmniej) się nie przyznawał (357-362).

Po trzecie, tworzy swoją własną opowieść o amerykańskim powojniu Miłosza. Choć książka Kołodziejczyk może niekiedy sprawiać wrażenie sprawozdawczej, warto zwrócić uwagę na stawiane przez autorkę akcenty. Te bowiem składają się na przemyślaną, kompleksową narrację, która kulminuje w przełomowym 1947 roku (gdy pozycja poety w kręgach dyplomatycznych się umacnia; s. 140), zmierza ku końcowi na początku lat 50., by znaleźć nieoczekiwane przedłużenie w drugiej połowie tej samej dekady za sprawą tomu Kontynenty, stawiającego starą twórczość w nowym, bardziej uniwersalnym świetle.

Na tym, jak sądzę, polega największy pożytek płynący z lektury Amerykańskiego powojnia Czesława Miłosza: na archiwistycznej skrupulatności autorki i umiejętności wychwytywania białych plam w dotychczasowym stanie badań. Oby przyszli interpretatorzy wykorzystali wnioski oraz inspiracje płynące $z$ tej książki.

\section{Bibliografia}

Kołodziejczyk E. 2015. Amerykańskie powojnie Czesława Miłosza, Warszawa: IBL. Miłosz C. 2001. Rodzinna Europa, Kraków: Znak. 